\title{
Decompression Sickness with Simultaneous Cranial and Spinal Involvement: A Case Report
}

\author{
Olgu: Kraniyal ve Spinal Tutulumun Eş Zamanlı İzlendiği Dekompresyon Hastalı̆̆ı
}

\begin{abstract}
Decompression sickness (DCS) causes venous and arterial embolization, resulting from decreased nitrogen solubility in the blood and tissues due to the rapid drop in external pressure, when rising to the surface after deep underwater dives. Neurological involvement is frequently seen in the medulla spinalis, but there may also be cranial involvement. A 36-year-old male patient, working as a professional diver, was brought to the emergency department with confusion, cerebellar syndrome findings, and paraplegia, soon after consecutive deep dives. Radiological examinations showed involvement of the bilateral cerebral and cerebellar hemispheres, along with the cervical and thoracic spinal cord. This patient with medulla spinalis and cranial involvement of DCS, observed simultaneously, was presented with follow-up clinical and radiological findings.
\end{abstract}

Keywords: Decompression sickness, stroke, embolism

$\ddot{O} \mathbf{z}$

Dekompresyon hastalığı (DKH), derin su altı dalışlardan sonra yüzeye çıkarken dış basıncın hızlı düşmesine bağlı ortaya çıkar. Kan ve dokularda bulunan azotun çözünürlüğünün azalması sonucu ortaya çıkan gaz baloncukları venöz ve arteryel embolizasyonlara neden olmaktadır. Nörolojik tutulum sıklıkla medulla spinalis ile sınırlıdır ancak serebral tutulum da eşlik edebilir. Otuz altı yaşında erkek hasta profesyonel dalgıç olarak çalışırken, tekrarlayan derin dalışları sonrasında ortaya çıkan akut başlangıçlı konfüzyon haline eşlik eden serebellar bulgular ve parapleji kliniğiyle başvurdu. Manyetik rezonans görüntülemede, bilateral serebral ve serebellar hemisferler ile servikal ve torakal spinal kordda çok sayıda iskemik alanlar izlendi. DKH'ye bağlı yaygın ve eş zamanlı medulla spinalis ve serebral tutulumun görüldüğ̈̈ bu olgu, klinik ve radyolojik izlem bulguları eşliğinde tartışılmıştır.

Anahtar Kelimeler: Dekompresyon hastalı̆ $\breve{g}_{1}$, inme, emboli

\section{Introduction}

Decompression sickness (DCS) is caused by a rapid decrease in the external pressure while rising to the surface after deep underwater dives. Gas bubbles with decreased nitrogen solubility in the blood and tissues cause venous and arterial embolization (1). Based on clinical symptoms, DCS is categorized into type 1 and type 2. Type 1 consists of symptoms involving the muscles, skeletal system, lymphatic and cutaneous circulation, whereas type 2 involves cardiopulmonary, neurological, and inner-ear symptoms (2). Neurological DCS is seen in an average of 2.7 per 10,000 divers (3). Neurological involvement is often limited to the spinal cord, but may also be cerebral. Spinal DCS mostly affects the lower cervical and lower thoracic regions and typically causes progressive transverse myelitis (4). In this article, we report the case of a patient with widespread and simultaneous cranial and spinal involvement due to DCS, with radiological findings.

\section{Case Report}

A 36-year-old male patient dived up to 30 meters, shortly after diving to a 26-meter depth. The patient was working at a fish farm as a professional diver, and he was admitted to the emergency department with a mild level of unconsciousness after he surfaced.

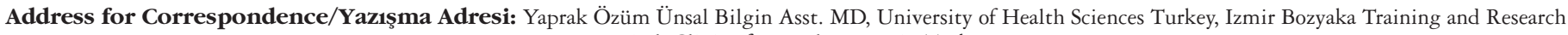
Hospital, Clinic of Neurology, Izmir, Turkey

Phone: +90 23225050 50-5206 E-mail: yaprakunsal@gmail.com ORCID: orcid.org/0000-0002-1124-8939

Received/Geliş Tarihi: 15.03.2020 Accepted/Kabul Tarihi: 13.04.2021

${ }^{\circ}$ Copyright 2021 by Turkish Neurological Society

Turkish Journal of Neurology published by Galenos Publishing House. 
The patient, whose confusion continued, was treated with hyperbaric oxygen therapy (HBOT) 8 hours after the event, with a preliminary diagnosis of DCS. However, this treatment could not be applied effectively due to his confused state. Neurological examination of the patient, 24 hours after the event, revealed confusion, limited orientation and cooperation, dysarthria, and verbal output limited to a few meaningful words. Pupils were normoisochoric, with positive direct and indirect light reflexes. In the primary position, third-degree nystagmus was detected with the fast phase hitting the left. The patient had urinary retention; therefore, urine was drained with a Foley catheter. Bilateral plantar responses were extensor and all deep tendon reflexes were increased. Vital signs and electrocardiogram were within normal limits. The routine hemogram evaluation revealed a white blood cell count of $26,000 / \mathrm{mm}^{3}$ and slightly elevated muscle enzymes, such as creatine kinase, alanine aminotransferase, and aspartate aminotransferase, which later regressed with hydration. The cranial diffusion magnetic resonance imaging (MRI) revealed large areas of acute diffusion restriction located bilaterally in the anterior and posterior commissure of the corpus callosum and bilaterally deep in the white matter (Figure 1). The cervical and thoracic spinal diffusion MRI revealed diffusion restriction in the entire blood supply area of the anterior spinal artery, as well as hyperintense myelomalacia areas in all the spinal segments in T2 sequences (Figure 2, 3). DCS was evaluated as type 2 after the examinations, and the first effective HBOT was administered 24 $\mathrm{h}$ after the event. Transthoracic echocardiography was performed for the possible etiology of intracardiac shunt, after observing that both the cranial and spinal involvements were within physiological limits. Electroencephalography was not planned for the patient because he gradually regained consciousness, and he was fully conscious on the third day.

In the neurological examination of the patient in the first period in which cooperation could be established, despite confusion for 3 days after the event, he was conscious, oriented, and cooperative, with normal speech. Pupils were normoisochoric, with bilateral direct and indirect light reflexes. In the horizontal plane, second-degree nystagmus was observed in the conjugate gaze, which hit the fast phase to the left. Diplopia and gaze paresis
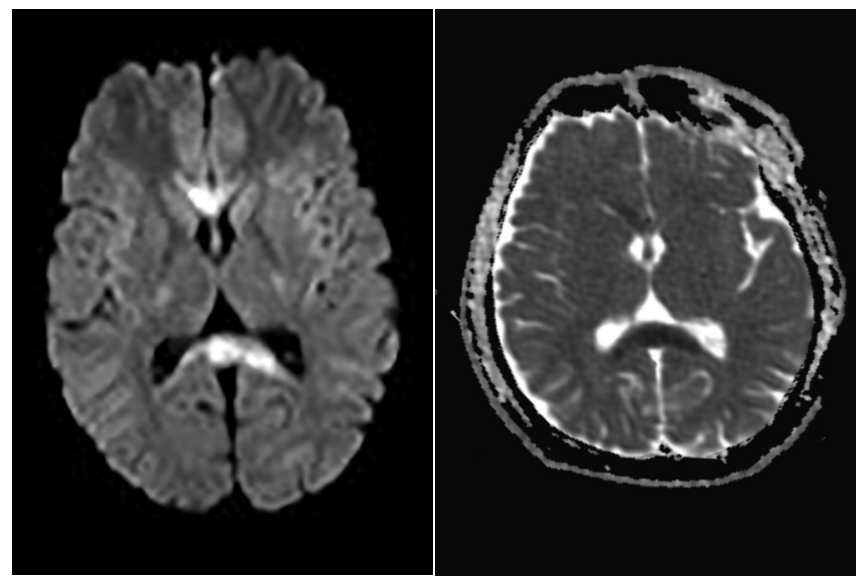

Figure 1. Admission day: Signal increase in the anterior and posterior commissures of the corpus callosum as revealed by diffusion-weighted imaging were not detected. Bilateral corneal reflexes were present. Facial asymmetry was not observed. Hyperesthesia in C3-T4 dermatomes and anesthesia below the T4 level were detected. Vibration and position senses were normal in the upper extremity, but absent in the bilateral lower extremities. The patient was quadriparetic, with muscle strength of $4 / 5$ in the bilateral upper extremities and $0 / 5$ in the bilateral lower extremities. Bilateral Hoffmann signs were negative, with positive bilateral Babinski signs. Deep tendon reflexes in the bilateral upper extremities were normoactive. Patella reflexes could not be observed bilaterally; however, Achilles reflexes were bilaterally normoactive. Cerebellar tests were not

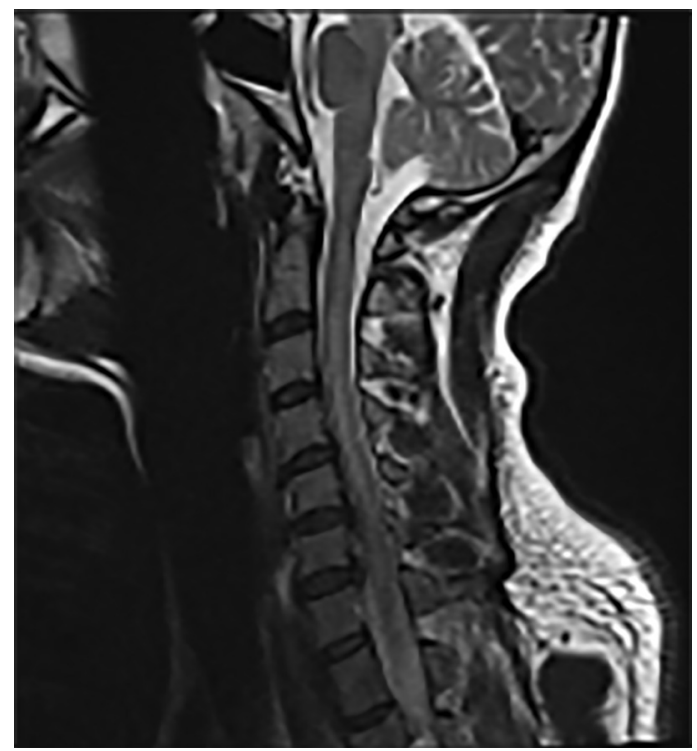

Figure 2. Hyperintense areas suggestive of myelomalacia in all the cervical and thoracic spinal segments in the cervical and thoracic magnetic resonance imaging of sagittal T2 sequences

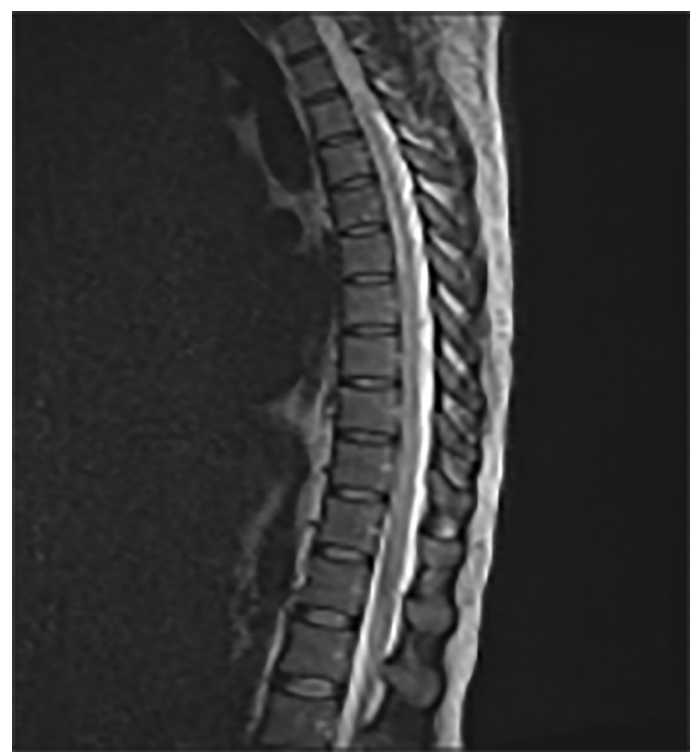

Figure 3. Hyperintense areas suggestive of myelomalacia in all the cervical and thoracic spinal segments in the cervical and thoracic magnetic resonance imaging of sagittal T2 sequences 
evaluated due to paresis. Urinary and stool retention was observed. Thus, follow-up was performed with a Foley catheter. Daily enema was applied due to constipation. In the recurrent neurological examination of the patient, after the fourth cycle of daily HBOT, the anesthesia level regressed to the T12 dermatome. On the seventh day of treatment, muscle strength recovered to $5 / 5$ in the bilateral upper extremities. The patient's confusion regressed by the third day and his muscle strength in the upper extremities was fully recovered at the end of the first week. Thereafter, he was transferred to the physical therapy and rehabilitation clinic for rehabilitation. At the first-month follow-up, the cranial, cervical, and thoracic MRI examinations of the patient, who was followed up with paraplegia, neurogenic bladder, and bowel involvement as well as a sensory defect at T12 level, revealed regressed areas of diffusion restriction detected in the first imaging and decreased T2 hyperintense changes (Figure 4, 5). At the third-month followup, he could maintain his standing balance, but was unable to mobilize, and was followed with an indwelling urinary catheter. The ischemic lesions observed in the spinal cord had regressed, as found at the sixth-month follow-up imaging, but an atrophic spinal cord appeared (Figure 6). At the first-year follow-up, he could walk without any assistive device, despite the widespread bilateral lower extremity spasticity.

\section{Discussion}

In DCS, the venous circulation bubbles migrate back from the vena cava and accumulate in the epidural vertebral venous plexus, leading to venous stasis, ischemia, and subsequently infarction. Gas bubbles in the white matter of the spinal cord cause axon destruction and pressure-induced ischemia. Spinal DCS leads to bleeding, axonal loss, myelin degeneration, and inflammation. Gas bubbles formed in the venous blood pass to the arterial side, in the presence of intracardiac right-to-left shunts (such as patent foramen

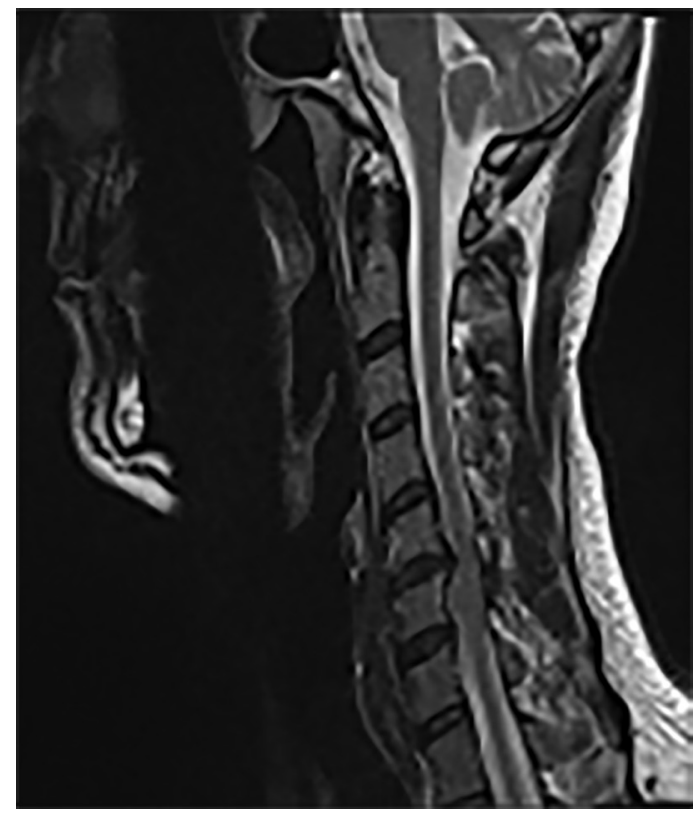

Figure 4. Reduction in T2 hyperintense changes at the first-month follow-up as revealed by the cervical and thoracic magnetic resonance imaging examinations ovale/atrial septal defect) (5). Cranial infarcts are explained in this way, but have also been reported to develop without a shunt. No intracardiac shunt was detected in the examinations performed on our patient. However, infarctions were observed in both the anterior and posterior circulation areas.

Patient history revealed three consecutive dives to a depth of 30 meters, which were repeated without paying attention to the decompression time. His neurological examination revealed vestibular and cerebellar findings as well as significant paraplegia.

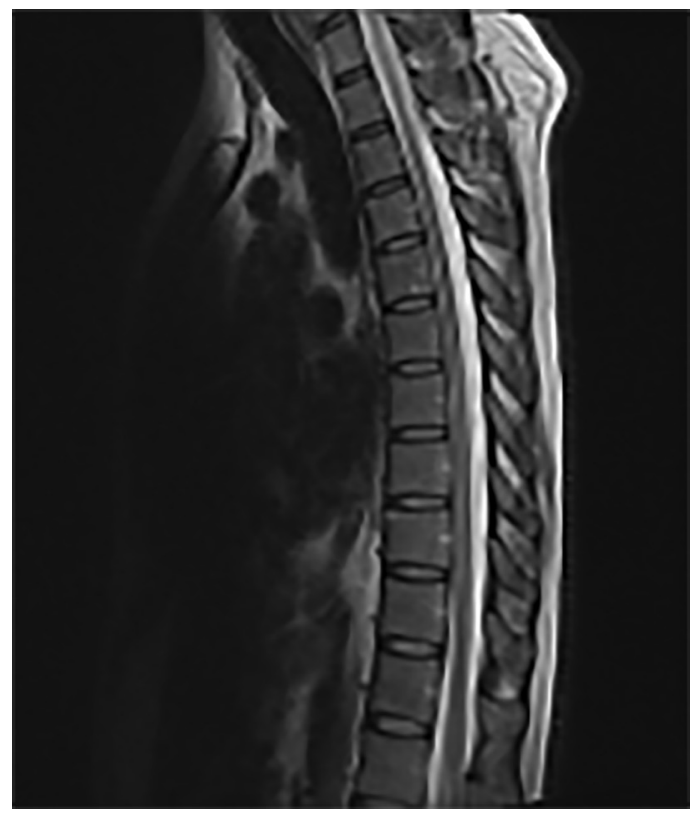

Figure 5. Reduction in $\mathrm{T} 2$ hyperintense changes at the first-month follow-up as revealed by the cervical and thoracic magnetic resonance imaging examinations

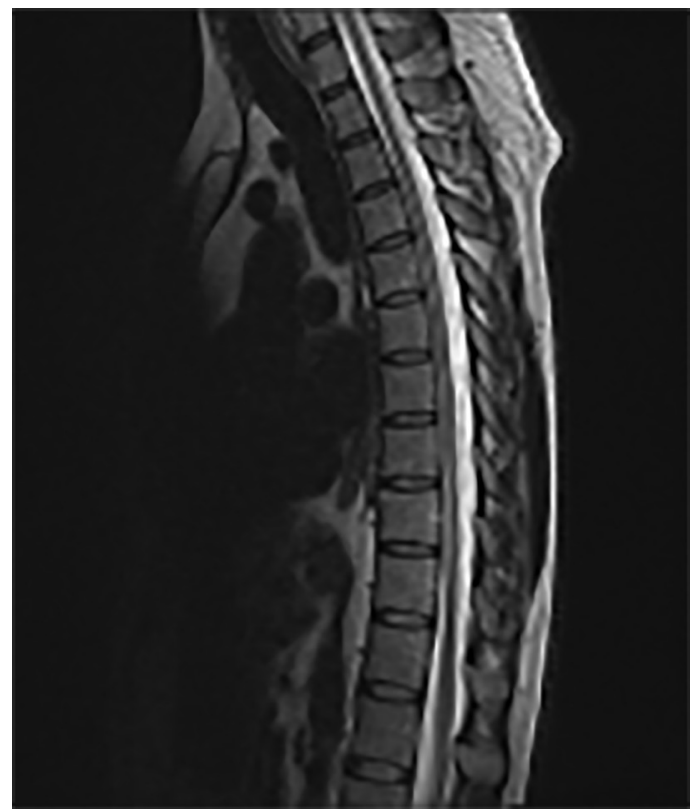

Figure 6. Atrophic spinal cord appearance in the imaging at the sixthmonth follow-up 
Radiological evidence of ischemia was found on T1, T2, fluidattenuated inversion recovery, and diffusion-weighted imaging cranial and spinal MRI examinations. In addition to standard imaging, Hutchinson et al. emphasized that the clinical use of diffusion tensor imaging in their study is beneficial in showing prognosis and guiding long-term treatment strategies for spinal DCS (6). A study by Seyithanoğlu et al. (7) showed that repeated hyperbaric exposure in divers and non-divers increased the risk of white matter damage, even in experienced healthy divers without neurological DCS.

Early initiation of HBOT in the treatment of DCS improves the recovery rate. A study by $\mathrm{Xu}$ et al. (8) revealed a $93 \%$ rate of complete recovery in those treated with HBOT within the first 6 hours, whereas the recovery rate was $75 \%$ in those treated after 36 hours. The first effective HBOT was performed in our patient after $24 \mathrm{~h}$, and severe sequelae findings continued for months, together with partial improvement. At the sixth-month follow-up, the patient was ambulatory with an assistive device.

DCS is a disease with a variable prognosis that affects all systems due to its pathophysiology. Thus, patients should be rapidly treated with HBOT, accompanied by necessary radiological examinations to verify the neurological examination findings.

Ethics

Informed Consent: Patient consent was obtained.

Peer-review: Externally peer-reviewed.

\section{Authorship Contributions}

Surgical and Medical Practices: Y.Ö.Ü.B., Concept: A.K., Design: R.R.B., Data Collection or Processing: Y.Ö.Ü.B., Analysis or Interpretation: R.R.B., Literature Search: A.K., Writing: Y.Ö.Ü.B.

Conflict of Interest: No conflict of interest was declared by the authors.

Financial Disclosure: The authors declared that this study received no financial support.

\section{References}

1. Pontier JM, Vallée N, Ignatescu M, Bourdon L. Pharmacological intervention against bubble-induced platelet aggregation in a rat model of decompression sickness. J Appl Physiol 2011;110:724-729.

2. Neuman TS. Arterial gas embolism and decompression sickness. News Physiol Sci 2001;17:77.

3. Vann RD, Butler FK, Mitchell SJ, Moon RE. Decompression illness. Lancet 2011;377:153-164.

4. Newton HB. Neurologic complications of scuba diving. Am Fam Physician 2001;63:2211-2216.

5. Gerriets T, Tetzlaff K, Liceni T, et al. Arteriovenous bubbles following cold water sport dives: relation to right to left shunting. Neurology 2000;55:17411743.

6. Hutchinson EB, Sobakin AS, Meyerand ME, et al. Diffusion tensor MRI of spinal decompression sickness. Undersea Hyperb Med 2013;40:23-31.

7. Seyithanoğlu MH, Abdallah A, Dündar TT, et al. Investigation of Brain Impairment using diffusion-weighted and diffusion tensor magnetic resonance 1maging in experienced healthy divers. Med Sci Monit 2018;24:8279-8289.

8. Xu W, Liu W, Huang G, et al. Decompression illness: clinical aspects of 5278 consecutive cases treated in a single hyperbaric unit. PLoS One 2012;7:e50079. 